\title{
Constitutional law and empire in interwar Britain: universities, liberty, nationality and parliamentary supremacy \\ DONAL K COFFEY*
}

National University of Ireland, Maynooth

\begin{abstract}
This article examines the influence of imperial law, law outside the UK but within the British Empire, on the development of British constitutional law in the interwar period. It first looks at public law within the universities. Four foundational textbooks in British public law are then analysed to assess the extent to which the academic exposition of constitutional law was influenced by imperial law. The influence of imperial law on the areas of liberty/habeas corpus and citizenship is then considered. The article concludes by re-examining the doctrine of parliamentary supremacy and argues that Dicey accepted a variant of the 'manner and form' objection in the final edition of his textbook completed before bis death.
\end{abstract}

Key words: imperial history; constitutional law; constitutional history; legal history; British history.

\section{Introduction}

The English jurist is not a sociologist; he is a lawyer, but he has been taught that he cannot be a lawyer unless he is also a historian. For all law (except of course the largest part of it which, being in legislation, tends to be ignored) is simply the scum left by the receding tide of history.

W Ivor Jennings 1

\footnotetext{
$\mathrm{T}$ he egress of the British constitution was the constitution of the British Empire. Based on the doctrine of the indivisible Crown, and fortified by legislation and common law, it came to govern many corners of the globe. The fundamentals of the British constitution including parliamentary supremacy remained a cornerstone of the constitution, although increasingly tempered in its usage by constitutional conventions in the self-governing parts of the Empire, called dominions after 1907. The field of British constitutional law in the early part of the twentieth century was therefore faced with a conundrum: whether to embrace imperial constitutional law and, if so, how exactly one might do it. The question became particularly complicated by the explosion in the number of constitutions, both dominion and colonial, in the Empire, for example the constitution of Australia which entered into force in 1901, that of the Union of South Africa in 1910, and the Irish Free

* Lecturer/Assistant Professor. The research underpinning this article was largely carried out while the author was based at the Max Planck Institute for European Legal History.

1 Ivor Jennings, 'A plea for utilitarianism’ (1938) 2 Modern Law Review 22, 27-28.
} 
State in 1922. Within the Empire, the final appeal to the Judicial Committee of the Privy Council (JCPC), controversial in many quarters, provided a means of ensuring continuity in the development of the common law in these jurisdictions, but also meant that the law lords were conversant with the contours of constitutional development in other countries. In the time period under consideration, the interwar period, the dominions were gradually asserting more independence, culminating in the political declaration of equality of status between the UK and the dominions in the Balfour Declaration of 1926 and legally in the Statute of Westminster 1931.

There has recently been renewed interest in the manner in which changes in constitutional theory were shaped by developments in other parts of the Empire. Peter Oliver's magisterial comparative work on Commonwealth constitutional theory has elaborated on the ways in which constitutional debates around the core concepts of British constitutional theory, in particular in relation to concepts of parliamentary supremacy, were shaped by developments in Commonwealth constitutional theory. ${ }^{2}$ Dylan Lino has drawn attention to the manner in which Empire shaped the work of Albert Venn Dicey. ${ }^{3}$ Harshan Kumarasingham and others have noted the way in which W Ivor Jennings' experience of empire shaped his constitutional thought. ${ }^{4}$ Bonny Ibhawoh has written about the influence of Nigerian cases on British law. ${ }^{5}$ The International Journal of Constitutional Law has also recently published a symposium on 'New Dominion Constitutionalism'. ${ }^{6}$

This paper aims to add to these constitutional histories by analysing the extent to which imperial law influenced domestic British constitutional law in the interwar period. Throughout this article, the term 'imperial law' will be used to refer to law that originates in a part of the Empire other than the UK. This is preferred to 'colonial law' as the jurisdictions were not always colonies. Imperial law may be a constitutional law or institution, a statute, a theory, or a case which originates outside the UK. It does not refer to laws made within the UK which extend to the Empire; these are noted explicitly in the text.

The article first gives some background as to the general history relating to tertiary education and constitutional law in the interwar period. This was informed by books on

2 Peter C Oliver, The Constitution of Independence: The Development of Constitutional Theory in Australia, Canada, and New Zealand (Oxford University Press 2005) in particular 54-110.

3 Dylan Lino, 'Albert Venn Dicey and the constitutional theory of empire' (2016) 36 Oxford Journal of Legal Studies 751; and 'The rule of law and the rule of empire: A V Dicey in imperial context' (2018) 81 Modern Law Review 739.

4 H Kumarasingham (ed), The Road to Temple Trees: Sir Ivor Jennings and the Constitutional Development of Ceylon: Selected Writings (Centre for Policy Alternatives 2015); H Kumarasingham (ed), Constitution-making in Asia: Decolonisation and State-building in the Aftermath of the British Empire (Routledge 2016).

5 Bonny Ibhawoh, Imperial Justice: Africans in Empire's Court (Oxford University Press 2013) 139-146. See also T O Elias, 'Nigeria's contribution to colonial law' (1951) 33 Journal of Comparative Legislation and International Law 49, 52-53.

6 See Mara Malagodi, Luke McDonagh and Thomas Poole, 'New dominion constitutionalism at the twilight of the British Empire: an introduction' (2019) 17 International Journal of Constitutional Law 1166; Peter C Oliver, "Dominion status": history, framework and context' (2019) 17 International Journal of Constitutional Law 1173; Luke McDonagh, 'Losing Ireland, losing the empire: dominion status and the Irish constitutions of 1922 and 1937' (2019) 17 International Journal of Constitutional Law 1192; Rohit De, 'Between midnight and republic: theory and practice of India's dominion status' (2019) 17 International Journal of Constitutional Law 1213; Mara Malagodi, 'Dominion status and the origins of authoritarian constitutionalism in Pakistan' (2019) 17 International Journal of Constitutional Law 1235; Rehan Abeyratne, 'Uncertain sovereignty: Ceylon as a dominion 1948-1972' (2019) 17 International Journal of Constitutional Law 1258; and Mara Malagodi, Luke McDonagh and Thomas Poole, 'The dominion model of transitional constitutionalism' (2019) 17 International Journal of Constitutional Law 1283. 
constitutional law from the period as well as articles written on constitutional law in the time period in the Law Quarterly Review, the Cambridge Law Journal, and Juridical Review. It then examines generally the treatment of imperial law in the four core constitutional textbooks from the 1920s and 1930s to assess the influence of imperial law on the academic treatment of constitutional law. The surveyed books are: D L Keir and F H Lawsons's casebook Cases in Constitutional Law; Arthur Berriedale Keith's An Introduction to British Constitutional Law; E C S Wade and G Godfrey Phillips' Constitutional Law; and W Ivor Jennings' The Law and the Constitution. ${ }^{7}$ It then builds on this general analysis by illustrating the manner in which imperial law played a particularly important part in two specific areas: citizenship and liberty. It closes by an analysis of Dicey's theory of parliamentary supremacy in the interwar period. It argues that Dicey accepted the manner and form objection to parliamentary supremacy, that this acceptance was overlooked in the Trethowan case which it may have influenced, and that the composition of the ninth edition of his textbook by E C S Wade meant that there has been a failure to appreciate the position that Dicey took on this matter towards the end of his life.

\section{Constitutional law in the universities}

The period under consideration for this paper naturally predated the explosion in academic research published in the field of constitutional law in recent years. The exposition of constitutional law remained, however, a key goal of law faculties in the UK at the time. Of these, the largest by student number in England were the Universities of Cambridge, Oxford and London. In the academic year 1933-1934 they attracted respectively 519, 500 and 307 students, while no other English law school had more than 100 students. $^{8}$

The syllabus of universities reflected the increasing importance of the Empire to students of the law, which might be thought to render British constitutional law permeable to imperial influences. Perhaps the best example here is from the University of London, where students could study a course on the constitutional law of the British Empire in their third year. ${ }^{9}$ More significantly, there was a personnel overlap; Professor John Hartman Morgan lectured both the third-year course and the first-year constitutional course in $1930 / 1931 .{ }^{10}$ In this time period, it makes sense to treat the University of London as a single faculty for the purposes of this paper, as the lecturers, professors and venues were shared between courses. ${ }^{11}$ In the interwar period, the University of London attracted professors who had been active in other parts of the Empire - Edward Jenks had been a professor at the University of Melbourne: indeed, he was the first professor of law at that university and lectured the introductory course in

7 D L Keir and F H Lawson, Cases in Constitutional Law (Oxford University Press 1928); Arthur Berriedale Keith, An Introduction to British Constitutional Law (Oxford University Press 1931); E C S Wade and G Godfrey Phillips, Constitutional Law (Longmans, Green \& Co 1931); W Ivor Jennings, The Law and the Constitution (University of London Press 1933).

8 Statistics taken from Edward Jenks, 'English legal education' (1935) 51 Law Quarterly Review 162, 179.

9 University of London, University College: Calendar Session MCMXXX-MCMXXXI (Taylor \& Francis 1930) 234.

10 Ibid 240, 243. For some examples of Morgan's works, see J H Morgan (ed), The New Irish Constitution (Hodder and Stoughton 1912); 'Dominion status' (1929) 9 Dalhousie Review 131; 'Introduction: remedies against the Crown' in G E Robinson, Public Authorities and Legal Liability (University of London Press 1925) xvii.

11 See Jenks (n 8) 171-172 and W L Twining, 'Laws' in F M Thompson (ed), The University of London and the World of Learning 1836-1986 (Hambledon Press 1990) 96-99. 
London until 1930, ${ }^{12}$ while Herbert A Smith had been a professor of constitutional law at McGill University before he lectured on the third-year course. ${ }^{13}$ Jenks was replaced in 1930 by W Ivor Jennings who had been based in Leeds and whose later time as Vice Chancellor of the University of Ceylon and as a constitutional expert in South Asia has seen renewed interest in recent academic literature. ${ }^{14}$ Sir Maurice Amos joined after Jennings as Quain Professor of Jurisprudence; he had already published The English Constitution by the time of appointment. ${ }^{15}$ Although he joined the faculty late in the period under consideration, it is also worth noting the Australian scholar R T E Latham, whose work during his brief life was very impressive. ${ }^{16}$

Universities at the time provided courses necessary for the education of imperial civil servants who would be sent overseas. ${ }^{17}$ This was bolstered by the attendance of students who would go on to become influential constitutional thinkers in their own countries in the lead into and attainment of independence; looking only at South Asia, Bernard Peiris of Ceylon, Chan Htoon of Burma, and V K Krishna Menon of India all studied law in London in the interwar period, while Liaquat Ali Khan of Pakistan studied law in the University of Oxford. The presence of formidable intellects from around the globe must have sharpened the constitutional debates that occurred in the metropole. Certainly, the constitutional developments within the Empire were live issues within the UK. In Trinity Term 1922 in the University of Oxford, for example, one question on the constitutional law and legal history exam was 'What is meant by dominion status?'18

The interwar period did not have a comparable amount of academic writing as one finds today, but it was nonetheless lively. It saw the establishment of the Cambridge Law Journal and the Modern Law Review. The establishment of the latter in 1937 was too late to influence the field in the time period under consideration, but the number of short notes and substantive articles on constitutional law that were generated in only three years was substantial. ${ }^{19}$ There were also a number of textbooks and monographs on constitutional law. The most significant, which will be surveyed in the next section were $\operatorname{Keir}^{20}$ and Lawon's ${ }^{21}$ Cases in Constitutional Law, E C S Wade ${ }^{22}$ and Phillips' 23 Constitutional Law, which first appeared in 1931, Keith's ${ }^{24}$ An Introduction to British Constitutional Law, published in the

12 For examples of Jenks' works, see Edward Jenks, The Government of the British Empire (as at the end of the year 1917) (John Murray 1918); ‘The Imperial Conference and the constitution’ (1927) 3(1) Cambridge Law Journal 13.

13 For examples of Smith's works, see Herbert A Smith, Judicial control of legislation in the British Empire' (1924-1925) 34 Yale Law Journal 277; 'The residue of power in Canada' (1926) 4 Canadian Bar Review 432.

14 Kumarasingham (ed), The Road to Temple Trees (n 4)'; Kumarasingham (ed), Constitution-making in Asia (n 4).

15 Maurice Amos, The English Constitution (Longmans 1930).

16 See Oliver (n 2) 85-91.

17 See J C H Macnair, 'The Indian civil service and the courts' (1928) 40 Juridical Review 266, 268. Jenks (n 8) 172.

18 F H Lawson, The Oxford Law School 1850-1965 (Oxford University Press 1968) 234. The interest was also alluded to in the Oxford casebook; see Keir and Lawson (n 7) vii.

19 See e.g. W I Jennings, 'The Ministers of the Crown Act, 1937' (1937) 1 Modern Law Review 145, 'Official Secrets Acts' (1938) 2 Modern Law Review 73; E C S Wade, 'Declaration of Abdication Act, 1936' (1937) 1 Modern Law Review 64, 'Regency Act, 1937' (1937) 1 Modern Law Review 66, 'The Law of Public Meeting' (1938) 2 Modern Law Review 177.

20 At the time Fellow and Dean of University College.

21 Later professor of comparative law.

22 Then a fellow of St John's College, subsequently Downing Professor.

23 Based at Gray's Inns at the time.

24 Professor of Sanskrit at the University of Edinburgh. 
same year, and Jennings' The Law and the Constitution, published in 1933. To this might be added minor works such as The English Constitution by Sir Maurice Amos, published in 1930, shortly before he became the Quain Professor of Jurisprudence. ${ }^{25}$

The pages of British journals such as the Law Quarterly Review often included articles on the constitutional law and development of other parts of the Empire. This was particularly true of Australia, with pieces from the Australian Solicitor-General Robert Garran, ${ }^{26}$ the former Premier of New South Wales W A Holman ${ }^{27}$ and, most famously, the Australian High Court judge Owen Dixon. ${ }^{28}$ In contrast, Juridical Review had a series of articles on Canadian constitutional law and history by the Dean of the University of Toronto law school W P M Kennedy, ${ }^{29}$ as well as articles on South Africa and Ireland by Keith. ${ }^{30}$ The Journal of Comparative Legislation and International Law contained the most overtly imperial bent, with articles from numerous jurisdictions, including from the indomitable Keith. The authors of articles in journals were often based overseas, such as D M Gordon who wrote articles on administrative law in the Law Quarterly Review. ${ }^{31}$

It is, of course, a subjective measurement to rank the strength of different law faculties, but it may help the reader to have some indication of the relative abilities of the law faculties in terms of constitutional law. The strongest faculty in the country at the time for constitutional law was the University of London, which numbered amongst its members Jennings, Jenks, Morgan, Amos, and Smith. ${ }^{32}$ The second strongest was Edinburgh, based solely on the prodigious output of Keith. ${ }^{33}$ Thereafter, it was Cambridge, primarily based on E C S Wade but also Arnold McNair, ${ }^{34}$ while Oxford suffered from the death of Dicey and failed to find anyone of sufficient stature to replace him in the immediate aftermath. ${ }^{35}$ It is worth noting in this regard that the ninth edition of Dicey was edited by E C S Wade in Cambridge, which provides some indication of the lack of a suitable candidate to take it over in Oxford. While this brief overview gives some idea of the background to the academic discourse surrounding British constitutional law in the interwar period, it is necessary to consider in more detail how the subject was approached in academic textbooks in order to give a more rounded impression of how it influenced constitutional law as a whole.

25 Amos (n 15).

26 Robert Garran, 'Development of the Australian Constitution' (1940) 40 Law Quarterly Review 202.

27 W A Holman, 'Constitutional relations in Australia: commonwealth and states' (1930) 46 Law Quarterly Review 502.

28 Owen Dixon, 'The law and the constitution' (1935) 51 Law Quarterly Review 590.

29 W P M Kennedy, 'Aspects of the administrative law in Canada' (1934) 46 Juridical Review 203, 'The workings of the British North America Acts, 1867-1931' (1936) 48 Juridical Review 57, 'The centenary of Lord Durham's mission to British North America, 1838-1938' (1938) 50 Juridical Review 136.

30 A Berriedale Keith, 'The status of the union of South Africa' (1934) 46 Juridical Review 155; 'The constitution of Eire’ (1937) 49 Juridical Review 256.

31 See e.g. D M Gordon, 'Administrative tribunals and the courts' (1933) 49 Law Quarterly Review 94. On Gordon, see Kent Roach, 'The administrative law scholarship of D M Gordon' (1989) 34 McGill Law Journal 1.

32 See e.g. H A Smith, 'Nature of our constitutional law' (1920) 36 Law Quarterly Review 140.

33 On Keith, see Ridgeway F Shinn, Arthur Berriedale Keith, 1879-1944: The Chief Ornament of Scottish Learning (Aberdeen University Press 1990); Oliver (n 2) 65-70.

34 Courtney Kenny had retired as Downing Professor of the Laws of England but was still publishing on constitutional law in this period; see e.g. 'The dominions and their mother country' (1925) 2 Cambridge Law Journal 157.

35 A L Goodhart produced some short articles e.g. 'Thomas v Sawkins: a constitutional innovation’ (1936) 6 Cambridge Law Journal 22. 


\section{Approaches to imperial law}

The approaches to imperial law varied from monograph to monograph, but there are certain common features that are worth pointing out before going on to consider the individual volumes. The first element that was common to most monographs was a separate section which dealt with the law of the Empire, including the Commonwealth. A typical example was the seventeenth edition of Stephen's Commentaries on the Laws of England, printed in 1922, volume I of which was on the topic of 'Public Law' and was compiled by Philip Landon, a fellow of Trinity College Oxford. In it, the first chapter deals with 'The meaning and scope of public law', and this is immediately followed by 'The British Empire'. ${ }^{36}$ Each of the textbooks under consideration here adopted a similar means of exposition with the exception of Jennings. ${ }^{37}$ Wade and Phillips' title of the section, 'The British Commonwealth', betrays a certain unfamiliarity of the authors with the subject area, as the British Commonwealth itself was confined to the dominions and the UK, whereas the territorial sweep of the section indicates it dealt with the entire Empire. ${ }^{38}$ As this subject was in essence internally cabined off from the other expositions of constitutional law, it will not be considered further here. Similarly, the expositions of martial law were based on foreign precedent except for an Irish case; Keir and Lawson felt obliged to note that an appeal to the House of Lords on an Irish issue was equally binding on English courts on a similar issue. ${ }^{39}$ Again, here, the topic was essentially separated from the development of British law. ${ }^{40}$ What will be considered below is where imperial law influenced the exposition or analysis of British law.

The geographical focus of the analysis was predominantly on Great Britain. The rather more complicated question about the position of Northern Ireland within the UK's constitutional firmament after the Government of Ireland Act 1920 was often simply ignored. Wade and Phillips, for example, were praised for including a section on local government in their textbook, but the more substantial question of Northern Ireland was dealt with in half a paragraph at the start of the section on 'the British Commonwealth' where it was included with the Channel Islands and the Isle of Man. ${ }^{41}$ Keith dealt with it in two pages. ${ }^{42}$ The constitutional arrangements of Northern Ireland were, however, the subject of two volumes by Arthur S Quekett, Parliamentary Draftsman to the Government of Northern Ireland, although the volumes largely reproduced the relevant statutory provisions relating to various topics. ${ }^{43}$ That this was the approach in UK constitutional law textbooks such as Wade and Phillips a full decade after the establishment of the Parliament of Northern Ireland gives some indication as to the lack of interest in developments outside Great Britain itself. This lack of interest was mitigated in the case of Scotland by the fact that specialist Scots law journals existed; articles published in Juridical Review often dealt with the particular constitutional

36 Philip A Landon, Volume I: Public Law in Edward Jenks (ed), Stephen's Commentaries on the Laws of England (17th edn, Butterworth \& Co 1922) 111-128.

37 Keith (n 7) 163-225; Wade and Phillips (n 7) 343-377; Keir and Lawson (n 7) 405-466.

38 Wade and Phillips (n 7) 343-377.

39 Keir and Lawson (n 7) 369-370.

40 See also Wade and Phillips (n 7) 335-339.

41 Ibid 343.

42 Keith (n 7) 159-160.

43 Arthur S Quekett, The Constitution of Northern Ireland: Part I The Origin and Development of the Constitution (HM Stationery Office 1928) and The Constitution of Northern Ireland: Part II The Government of Ireland Act, 1920 and Subsequent Enactments (HM Stationery Office 1933). 
anomalies that existed in Scotland at the time, for example the prerogative in Scotland, ${ }^{44}$ or whether there was any means to impeach a Lord of Session. ${ }^{45}$ Given the paucity of coverage of an integral part of the UK, it might be thought likely that academic treatment of constitutional law paid little attention to examples from imperial law. In fact, imperial law was present in each of the monographs surveyed, although with varying degrees of integration into the main analytical sections.

Keir and Lawson's book was a casebook, which left less space for analytical sections on constitutional law. Notwithstanding this fact, there were a number of precedents from imperial jurisdictions relied upon; amongst other topics, the JCPC was canvassed for the relationship between the Crown and the court, ${ }^{46}$ and in relation to parliamentary privilege. ${ }^{47}$ More interestingly, it included the Cape of Good Hope Supreme Court decision in Reg $v$ Smith relating to the responsibility of soldiers when obeying orders that were not manifestly illegal in their section on military law. ${ }^{48}$ Keir and Lawson also dealt with the imperial dimension in some depth in relation to the question of nationality, which we will consider below.

As might be expected, Keith's interest in the Commonwealth and Empire meant that imperial examples were studded throughout his exposition of the British constitution. This touched on straightforward exposition of constitutional practice, such as that relating to the grant of honours ${ }^{49}$ or the Crown's powers in the colonies; 50 in providing examples of constitutional innovations that had been tried (and often failed) within the Empire, such as the use of extern ministers in the Irish Free State ${ }^{51}$ or the referendum; ${ }^{52}$ and in a description of imperial arrangements, such as in relation to the JCPC and the possibility of a Commonwealth Tribunal. ${ }^{53}$ It entered into the consideration of the Church of England, ${ }^{54}$ the privileges of Parliament, ${ }^{55}$ and the construction of statutes. ${ }^{56}$

In his examination of the Crown, Keith drew attention to the fact that the Imperial Conference in 1930 had established that the line of succession was only to be varied with the concerted action of the members of the Commonwealth, although this led him to conclude that no parliament except Westminster could vary the succession to the throne which was shown to be false, at least temporally, by the actions of the Irish and South African Parliaments in the abdication crisis of 1936. Moreover, he drew attention to the

44 Hugh R Buchanan, 'Some aspects of the royal prerogative' (1923) 35 Juridical Review 49.

45 J R Philip, 'The judicial immunity of the Lords of Session' (1927) 39 Juridical Review 1.

46 The authority relied upon was In re Lord Bishop of Natal (1864-1865) 3 Moo PCC (NS) 115; see Keir and Lawson (n 7) 272, 278-282.

47 Keir and Lawson (n 7) 71.

48 Keir and Lawson (n 7) 340, 348-351.

49 Keith (n 7) 64.

50 Ibid 83.

51 Ibid 55.

52 Ibid 107-109.

53 Ibid 132-133. On the Commonwealth Tribunal, see Donal K Coffey, 'The failure of the 1930 Tribunal of the British Commonwealth of Nations: a conflict between international and constitutional law' in Ignacio de la Rasilla and Jorge E Viñuales (eds), Experiments in International Adjudication: Historical Accounts (Cambridge University Press 2019) 240.

54 Keith (n 7) 155-156, 158.

55 Ibid 116.

56 Ibid 126. 
fact that this might mean secession from the Commonwealth was not legally possible, although the South Africans disagreed on this point. ${ }^{57}$

Wade and Phillips' book utilised imperial law less frequently than Keith, but it was still integrated into a number of different topics, from conventional limitations on parliamentary sovereignty, ${ }^{58}$ to the reference jurisdiction of the JCPC, ${ }^{59}$ constitutional guarantees of rights ${ }^{60}$ and Crown forces. ${ }^{61}$ It was the most substantial new textbook on constitutional law, but the references to imperial law were comparatively sparse. The copies of executive documents to be found in the appendices, particularly appendix $\mathrm{C}$, do contain examples of copies of important colonial documents, for example that establishing the constitutional structure of Fiji. ${ }^{62}$

Jennings' The Law and the Constitution contains relatively few references to imperial law with two major exceptions. In the majority of the textbook, the dominions are referenced for relatively straightforward assertions of fact, such as the proclivity towards written constitutions $^{63}$ or the position of the courts. ${ }^{64}$ Jennings does, however, integrate a discussion of developments in imperial law into those parts for which he is most well known: constitutional conventions and parliamentary supremacy. It should be noted that Jennings had the benefit of the passage of the Statute of Westminster in 1931, compared to the other authors surveyed, but it must also be admitted that he drew on the Report of the Conference on the Operation of Dominion Legislation and Merchant Shipping in 1929, which would have been available to Keith and Wade and Phillips. Conventions are associated with Jennings' critique of Dicey, and the discussion of the role that conventions had come to play in the relations between the members of the Commonwealth, in particular with reference to the Irish Free State, take up a large portion of the discussion on the topic: ${ }^{65}$ similarly, with the discussion on parliamentary supremacy, which contains numerous asides on the constitutional structure of the dominions and, of course, the introduction of the Trethowan case to a British audience. ${ }^{66}$

Each of the textbooks considered integrated imperial law into the exposition of British constitutional law. The slightest degree of integration was to be found in Wade and Phillips' book and Keir and Lawson's casebook. Jennings integrated imperial law into the most memorable elements of his book, but overall to a lesser degree than Keith, who utilised his vast knowledge of imperial law as a guide to many facets of British constitutional law. Having given a basic overview of the textbooks under consideration, it is useful to demonstrate how imperial law influenced the development of British constitutional law in more depth in specific areas: citizenship and liberty/habeas corpus. In order to do this, we will expand our analysis beyond the four textbooks contained in this section but refer to them where appropriate.

57 Ibid 34. On secession, see Donal K Coffey, “The right to shoot himself”: secession in the British Commonwealth of Nations' (2018) 39 Journal of Legal History 117. On the abdication crisis, see Donal K Coffey, 'British, Commonwealth, and Irish responses to the abdication of King Edward VIII' (2009) 44 Irish Jurist 95.

58 Wade and Phillips (n 7) 56-57.

59 Ibid 156.

60 Ibid 286.

61 Ibid 322, 325.

62 Ibid 420-446.

63 Jennings (n 7) 29.

64 Ibid 37, 211.

65 Ibid 81-88, 93-99, 105-106.

66 Ibid 114-115, 120-121, 123-126, 131-135, 140-141, 153, 155. 


\section{Citizenship}

In the interwar period, the great Australian historian of the Commonwealth William Keith Hancock left his chair in the University of Adelaide to become a professor at the University of Birmingham. In 1937, the first volume of his survey of Commonwealth affairs was published, the subtitle of which, 'Problems of Nationality', gave an indication of how important the question of nationality and citizenship had become in the interwar Empire. ${ }^{67}$ The legislative underpinnings of British citizenship after the First World War were primarily set by the British Nationality and Status of Aliens Acts 1914 and 1918 which stated a British subject included 'any person born within His Majesty's dominions and allegiance'. ${ }^{68}$ This was supplemented by an explicit recognition that Part II of the 1914 Act, which set out rules governing the naturalisation of aliens, did not apply to the dominions unless adopted by the legislature of the relevant dominion. ${ }^{69}$ The significance of this legislation may be seen from the extracts directly presented in Keir and Lawson. ${ }^{70}$

This meant that the provisions relating to British subjecthood were entangled with the dominions. The growth of nationalist movements in South Africa and the Irish Free State, with an emphasis on nationalities distinct from British subjecthood, further complicated the area. In the Irish Free State, the government relied upon Article 2 of the Constitution to issue passports which did not mention that the holders were British subjects; these passports were confiscated by British consular officials in London when they were presented for special endorsement, and new passports were issued in their place. ${ }^{71}$

It is hardly surprising, therefore, to find developments in this area that integrate the imperial dimension. A prominent example of this is Dicey's A Digest of the Law of England with Reference to the Conflict of Laws, which between its second edition in 1908 and its third in 1922 added a co-author in Keith. The shift in tone in relation to subjecthood is notable. From the second edition:

But every person born within the British dominions does, with very rare exceptions, enjoy at birth the protection of the Crown. Hence, subject to such exceptions, every child born within the British dominions is born 'within the ligeance,' as the expression goes, of the Crown, and is at and from the moment of his birth a British subject; he is, in other words, a natural-born British subject. ${ }^{72}$

In contrast, the third edition is expressed as follows:

This rule expresses the fundamental principle governing the law of British nationality, that every person born within any part of the British dominions (n) is as and from his birth a natural-born British subject.

67 W K Hancock, Survey of British Commonwealth Affairs: Volume I Problems of Nationality (Oxford University Press 1937).

68 British Nationality and Status of Aliens Act 1914, s 1.

69 Ibid s 9.

70 Keir and Lawson (n 7) 284-286. See also Wade and Phillips (n 7) 180-184.

71 On this question, see Joseph O'Grady, 'The Irish Free state passport and the questions of citizenship' (1929) 26 Irish Historical Studies 396; Mary Daly, 'Irish nationality and citizenship since 1922' (2001) 32 Irish Historical Studies 381; Donal K Coffey, Constitutionalism in Ireland, 1932-1938: National, Commonwealth, and International Perspectives (Palgrave Macmillan 2018) 59-65.

72 A V Dicey, A Digest of the Law of England with Reference to the Conflict of Laws (2nd edn, Steven \& Sons 1908) $166-167$. 
$\mathrm{N}$. This includes the territory of another kingdom united by a personal union with the British Crown. ${ }^{73}$

The third edition might be thought to express the conventional view of British subjecthood, based as it was on Calvin's case, but it is notable that the change occurred and specifically referred to a 'personal union'. It can readily be appreciated how this might be controversial as, while the book was being compiled, there was a war raging in Ireland in which a large body of the population sought full independence from the UK. If what was to result from this war was a personal union between a constitutional monarch in Ireland and the UK, the formulation above would have preserved British subjecthood for anyone born in Ireland. The vexed question of citizenship was to play out in that jurisdiction for the next 26 years, and the provisions of section 33(2) of the Irish Nationality and Citizenship Act 1935 which sought to repeal the common law relating to British nationality was treated as not being applicable outside Ireland by the UK. It was only fully laid to rest with the passage of the Ireland Act 1949.

A standard imperial case which was present in the books of the time was the JCPC case of De Jager $v A G$ of Natal in relation to the concept of allegiance when a territory was invaded. ${ }^{74}$ The JCPC further considered the link between the dominions and nationality, in particular what was meant by 'common status' of British nationality throughout the Empire; at the time of writing of the monograph, the Statute of Westminster was not yet in force and the Colonial Laws Validity Act 1865 meant that the provisions of the British Nationality and Status of Aliens Acts could not then be repealed as they were enshrined in a Westminster statute (the alternative Irish theory about the applicability of the 1865 Act in the Free State was apparently unknown to the authors). ${ }^{75}$ Keir and Lawson included in their casebook the text of the oaths taken by British MPs and Irish Teachtaí Dála (members of the Irish Lower House). ${ }^{76}$ The question of the Irish oath had been controversial as it was seen by some as a form of imperial control and was to prove a particular sticking point in Anglo-Irish relations in the 1930s after Éamon de Valera assumed the presidency of the Executive Council. The link between the allegiance and the status of the subject presented a particularly obvious legal nexus between British constitutional and imperial law because of the statutory underpinnings. In the next section, we will see that imperial case law could influence the development of English jurisprudence.

\section{Liberty/habeas corpus}

Writing in 1935, E C S Wade claimed:

Opinions differ widely as to the conception of liberty, but so far as the lawyer is concerned, the rule of law, in the sense of a state of regular law in contrast to arbitrary régime, still prevails within the Empire, whatever may be the conditions elsewhere, and with the future we are not immediately concerned. ${ }^{77}$

73 A V Dicey and Arthur Berriedale Keith, A Digest of the Law of England with Reference to the Conflict of Laws (3rd edn, Steven \& Sons 1922) 170.

74 Wade and Phillips (n 7) 182; Keith (n 7) 142-145; Amos (n 15) 176-179; Keir and Lawson (n 7) 288, 291293.

75 Wade and Phillips (n 7) 182-184. On the Irish theory, see Thomas Mohr, 'The Colonial Laws Validity Act and the Irish Free State' (2008) 43 Irish Jurist 21. Keith took a similar approach to Wade and Phillips, though with less emphasis on the 1865 Act; see Keith (n 7) 142-145.

76 Keir and Lawson (n 7) 288.

77 E C S Wade, 'Constitutional law' (1935) 51 Law Quarterly Review 235, 236-237. 
A similar sentiment can be traced in Latham's Australia and the British Commonwealth written in 1929, which commences with the chapter 'The principle of freedom'.78 Keith introduced a note of caution in terms of such a sweeping claim in regard to the Empire, noting the censorship and 'the most repressive law against political opponents known in modern British law' in the Irish Free State. ${ }^{79}$ It is not entirely clear what he attributed this to, as he mentioned the 'continental fashion' of constitutional codification of rights in the Free State, but equally notes that it was amendable by ordinary legislation under Article 50, which would have made it closer to the Westminster model of parliamentary sovereignty. The law to which he referred was the Public Safety Act 1927, which provided in section 3 that every provision of the Act which was in contravention of the Irish Constitution was to be an amendment of that Constitution, but only for as long as the Act was in force. ${ }^{80}$ This was followed by an even more draconian amendment of the Constitution in 1931, too late for inclusion in Keith's book, but drawing into question the issue of 'liberty' within the Empire.

The case of Eleko v Officer Administering Nigeria (No 1) ${ }^{81}$ concerned whether or not an applicant for habeas corpus had the right to apply successively to different judges on a petition, or whether, if it was heard once, that meant no further applications could be made. Hailsham LC argued that the right was a successive one:

If it be conceded that any judge has jurisdiction to order the writ to issue, then in the view of their Lordships each judge is a tribunal to which application can be made within the meaning of the rule, and every judge must hear the application on the merits. It follows that, although by the Judicature Act the Courts have been combined in the one High Court of Justice, each judge of that Court still has jurisdiction to entertain an application for a writ of habeas corpus in term time or in vacation, and that he is bound to hear and determine such an application on its merits notwithstanding that some other judge has already refused a similar application. The same principle must apply in the case of the judges of the Supreme Court of Nigeria. ${ }^{82}$

This had potentially far-reaching implications because the law in Nigeria at the time was based on the English Common Law - if the reasoning of the Privy Council was correct, it could also apply within England itself. It seems to have initially been treated as accurately stating the law as it applied in England; in 1930 the Court of Appeal in In Re Carroll did not question the 'exhaustive examination' that was carried out by the Privy Council. ${ }^{83}$ It was accepted as stating the law in relation to the Habeas Corpus Act 1679 in Keith's textbook on British Constitutional Law ${ }^{84}$ and also by Wade and Phillips, who referred to it as a 'curious case'. ${ }^{85}$ Notwithstanding this development, when it came to be considered directly by the Queen's Bench Division in Re Hastings (No 2) (55a $^{\text {a }}$ the court took the view that the opinion was incorrect and that, if a divisional court had previously heard the petition, then no subsequent application could be made.

78 See also the comments of the former Chief Justice of Ceylon, A Wood Renton, 'A century of colonial juridical policy’ (1931) 43 Juridical Review 287, 291.

79 Keith (n 7) 145-146. The use of the term 'British' here is interesting, as it seems to include 'Irish' within 'British', which may be a reference back to the idea of British subjecthood. See also ibid 31.

80 Donal K Coffey, 'The judiciary of the Irish Free State' (2011) 33 Dublin University Law Journal 61, 65-67.

81 (1927) UKPC 127, [1928] AC 459. For the background to the cases see Ibhawoh (n 5).

82 Eleko (n 81) 468.

83 (1931) 1 KB 104.

84 Keith (n 7) 147.

85 Wade and Phillips (n 7) 293.

85a [1959] 1 QB 358. 
In the second case concerning Eshugbayi Eleko, Eleko v Officer Administering Nigeria (No 2), ${ }^{86}$ Lord Atkin held:

In accordance with British jurisprudence no member of the executive can interfere with the liberty or property of a British subject except on the condition that he can support the legality of his action before a court of justice. And it is the tradition of British justice that Judges should not shrink from deciding such issues in the face of the executive. ${ }^{87}$

This second case has had a more successful run than the first, immediately being cited in the Law Quarterly Review ${ }^{88}$ and later cited with approval in a number of British cases including inter alia, Zamir $v$ Secretary of State for the Home Department. ${ }^{89}$ Notwithstanding the impact of the decisions, it is interesting to consider the treatment of these cases by E C S Wade in the 1935 Law Quarterly Review:

The great writ of Habeas Corpus played its part even in the emergency period of 1914-20, though it has now reverted to its modern function of providing at home a means for settling disputes with the proprietors of orphanages ( $R e$ Carroll), and abroad of affording loopholes of escape for deposed African chiefs (Eshugbayi Eleko v Government of Nigeria; Eshugbayi Eleko v Government of Nigeria (No 2)). The very rarity of its employment shows the efficacy with which it preserves personal liberty. ${ }^{90}$

The description of the Eleko cases here might be treated as being a joke by Wade were it not for the tendency of his writing to disclose a hostility to foreigners. It is worth noting, for example, in a textbook on constitutional law, Wade and Phillips included the following passage:

The policy of admitting or excluding aliens is not, of course, solely governed by the desire to check elements of possible disorder. For example, the admission of large numbers of aliens from countries where low wages prevail may have the effect of lowering wages to starvation point in unorganised trades in this country. Moreover, the habits of such people may have a demoralising effect in the crowded areas where they settle. ${ }^{91}$

This passage is not concerned with any provision of statutory law or case law and may be taken to accurately reflect the views of the authors on a question unrelated to the ostensible subject matter of the textbook - constitutional law. Although Eleko was a British subject and not an alien, the hostility disclosed in this passage provides a context, an ugly context, in which one must consider Wade's assessment of the Eleko cases.

\section{Parliamentary supremacy}

The most famous development from the time period under consideration concerns the 'manner and form' objection to parliamentary supremacy. Dicey contended that parliamentary supremacy meant that there was no legal limit on what the Crown in Parliament (that is, a Bill duly passed by both Houses to which royal assent had been given) could enact, save that no Parliament could bind a successor. The objection that arose in relation to this theory was whether or not the procedure by which laws were

86 [1931] AC 662.

87 Ibid 670 .

88 D M Gordon, “Administrative” tribunals and the courts' (1933) 49 Law Quarterly Review 94.

89 [1980] AC 930.

90 Wade (n 77) 238. Case references omitted.

91 Wade and Phillips (n 7) 178-179. 
enacted could be changed, imposing a procedural limitation on the Crown in Parliament. The question arose in a case in New South Wales, the Trethowan case. ${ }^{92}$ In Trethowan the government of Jack Lang attempted to abolish the Upper Chamber without submitting the Bill to achieve this to a referendum, a procedural requirement which had been inserted by the previous Conservative government. They inserted section 7A which provided, under subsection (2) that a Bill to abolish the Legislative Council 'shall not be presented to the Governor for his Majesty's Assent' until it had been approved in a plebiscite. ${ }^{93}$ The court case occurred before royal assent had been given, but after passage by both houses, and turned on whether or not the amendment changed the 'manner and form' in which legislation had to be passed; a phrase derived from section 5 of the Colonial Laws Validity Act 1865. The High Court of Australia and the JCPC famously held that this restriction was valid, and that the Bill could not be presented to the governor for royal assent. In 1933, Jennings introduced the case as evidence for the proposition that the Crown in Parliament could change the rules governing its own composition. ${ }^{94}$ This was the basis of the 'manner and form' objection to the Diceyan model of parliamentary supremacy. ${ }^{95}$

This conventional history overlooks the fact that Dicey had adopted the procedural objection, albeit not called 'manner and form', before he passed away. The issue was considered in relation to the Parliament Act 1911 in the eighth edition of his classical textbook published in 1915. The eighth edition preserved the body of the text from the seventh, published in 1908, to which he added a lengthy introduction of almost 100 pages, including an extended section on the Parliament Act. The Act provided a procedure by which Acts of Parliament could be passed by the House of Commons and Crown acting in concert, without the need for approval by the House of Lords.

The question that confronted Dicey, therefore, was how this new procedure fitted into the British constitutional scheme. Dicey argued: '[t]he simple truth is that Parliament Act has given to the House of Commons ... the power of passing any Bill whatever, provided always that the conditions of the Parliament Act, section 2, are complied with. ${ }^{96}$ The decisive analytical paragraph is on page xxiv as follows:

In these circumstances it is arguable that the Parliament Act has transformed the sovereignty of Parliament into the sovereignty of the King and the House of Commons. But the better opinion on the whole is that sovereignty still resides in the King and the two Houses of Parliament. The grounds for this opinion are, firstly, that the King and the two Houses acting together can most certainly enact or repeal any law whatever without in any way contravening the Parliament Act; and, secondly, that the House of Lords, while it cannot prevent the House of Commons from, in effect, passing under the Parliament Act any change of the constitution, provided always that the requirements of the Parliament Act are complied with, nevertheless can, as long as that Act remains in force, prohibit the

92 Trethowan v Peden [1931] 31 New South Wales Law Reports 183 for the New South Wales Supreme Court (Peden was a professor in the University of Sydney Law School); Attorney-General (NSW) v Trethowan [1931] HCA 3 for the High Court of Australia; [1932] UKPC 1 for the JCPC decision.

93 Sub-s 6 provided that any Bill to amend the procedure also had to follow the procedure.

94 Jennings (n 7) 123-124.

95 It is not possible here to list the numerous publications that relate to the debate on parliamentary supremacy. One classical contribution that still merits reading is R F V Heuston, Essays in Constitutional Law (2nd edn, Steven \& Sons 1964) 6-29. For modern contributions, see Jeffrey Goldsworthy, Parliamentary Sovereignty: Contemporary Debates (Cambridge University Press 2010) and Michael Gordon, Parliamentary Sovereignty in the UK Constitution: Process, Politics and Democracy (Hart 2015).

96 A V Dicey, Introduction to the Study of the Law of the Constitution (8th edn, Macmillan \& Co 1915) xxiii. 
passing of any Act the effectiveness of which depends upon its being passed without delay. ${ }^{97}$

What Dicey does not do in this passage is adumbrate any substantive limitation on the powers of the Commons and Crown under the Parliament Act, which he concedes can pass 'any change of the constitution'. The only limitation is actually the procedural requirement identified in the Parliament Act itself; which, slightly ironically, is simply a manner and form requirement to the manner and form objection. Dicey does not state that the power that the Commons and Crown enjoy was a type of delegated legislation (considered in more detail below), and his argument in favour of the conventional 'Crown in Parliament' model does not detract in any way from the claims that the 'Crown in the Commons' could make. He merely restates that the Crown in Parliament still possesses parliamentary supremacy, which, of course, proponents of the manner and form objection also concede.

The view that is commonly attributed to Dicey had been abandoned in its strictest form by Dicey himself before he passed away. The fact that this point has been obscured may be attributed to four principal reasons. First, the High Court of Australia, in particular Owen Dixon who publicised the decision academically thereafter, ${ }^{98}$ did not refer to Dicey's changed views. Second, in the first generation of academic treatment of the question, particularly by Jennings, this point was not canvassed. Third, the ninth edition of Dicey, which was edited by E C S Wade, did not contain the foreword where Dicey adopted this view. Fourth, H W R Wade's 're-statement' of what he claimed to be the orthodox view in 1955 distorted Dicey's actual views, primarily because it was based on the ninth edition. ${ }^{99}$

In Australia, the eighth edition of Dicey was in common usage. It was the core textbook of the law schools at the University of Melbourne and the University of Sydney. The fact that this edition was in common use in Australia at the time means it is a reasonable inference that the contents of it would be known to Australian jurists at the time. Granted, there are no references to Dicey in Trethowan at the High Court level, but one finds it sprinkled quite liberally in the decision of the Supreme Court of New South Wales the previous year, particularly in the decision of Street CJ and the submissions of H V Evatt. ${ }^{100}$ This does not prove that Dicey's views were the genesis of the decision in Trethowan, simply that they may have been known, and an alternative Australian pathway can be found in the case of Taylor $v$ Attorney-General (Qld), ${ }^{101}$ which foreshadowed many of the points later made in Trethowan. Nonetheless, it is possible that the analysis may have been influenced by Dicey's eighth edition. Despite this, the key academic texts which introduced the reasoning of the case immediately thereafter, Jennings in his textbook and Dixon in the Law Quarterly Review, did not refer to the Parliament Act argument, which languished in obscurity.

The ninth edition of Dicey's textbook, written after his death, was first published in 1939 under the editorship of E C S Wade. It is significant because it omitted the passage quoted above in relation to the Parliament Act. Wade made the decision to omit certain

97 Ibid xxiv.

98 Dixon (n 28).

99 See H W R Wade, 'The basis of legal sovereignty' (1955) Cambridge Law Journal 172, 184. On Wade’s arguments see Richard S Kay, 'Constitutional change and Wade's ultimate political fact' (2016) University of Queensland Law Journal 31. Wade's insistence that what was being propounded were 'orthodox' principles may also be seen in Wade and Phillips (n 7) 25.

100 Trethowan v Peden [1931] 31 New South Wales Law Reports 183, 198, 200.

101 [1917] HCA 45. 
portions of the introduction on the basis that they dealt with contemporary matters that were not yet settled law, including female suffrage and proportional representation, and to summarise other elements. ${ }^{102}$ Dicey's examination of the Parliament Act was omitted, and only the conclusion was left: 'His conclusion was that sovereignty still resided in the King and the two Houses of Parliament, but that the Act had greatly increased the share of sovereignty possessed by the House of Commons.' 103 The body of the text contained in the text of the ninth edition, however, was that from 1908, namely the edition before the passage of the Parliament Act.

The significance of the difference between the eighth and ninth editions of Dicey's textbook can be more fully appreciated when considering what is regarded as the classical re-statement of Dicey's views by H W R Wade in the 1955 Cambridge Law Journal. That article referred repeatedly to Dicey, but only to the ninth edition. ${ }^{104} \mathrm{H} \mathrm{W} \mathrm{R}$ Wade appears to have relied upon E C S Wade's summary of Dicey which was not, however, a full reflection of Dicey's views towards the end of his life. Moreover, H W R Wade's argument in relation to the question of manner and form simply sought to evade the crux of the issue. Considering the potential application of Trethowan to the UK, for example, Wade presents the following matrix: 'Next suppose that Parliament, wishing to retrace its steps, passes a repealing Act by its ordinary procedure, with no referendum, and the royal assent is duly given. Is the repeal effective?' 105 This overlooks a key, and controversial, element of the Trethowan litigation - the case took place before royal assent had been given. The repealing statute that Wade's example rests on would not yet be in force, it would still be a Bill pending the royal assent, so the argument constructed on that basis cannot proceed. ${ }^{106}$ This sleight of hand can also be seen in editions of E C S Wade and Phillips' book written after Trethowan was handed down - Trethowan raises the question of what the courts should do before the Bill has been presented for royal assent, and the answer proceeds on the basis of 'an Act of Parliament which had been duly promulgated'. ${ }^{107}$ It would, of course, be possible to argue that such a case would not be justiciable as a proceeding in Parliament, but that would be open to the counter-argument that the provisions regulating non-justiciability of proceedings in Parliament could be waived by virtue of parliamentary supremacy. In any event, the argument was not canvassed, and the key element of Trethowan was simply ignored, which allowed H W R Wade to simply set out what force of law an Act of Parliament had.

A final point raised by H W R Wade that featured in the Jackson v Attorney General 108 litigation was that the legislation passed under the Parliament Act 1911 was, in fact, delegated legislation. This delegated legislation argument was not considered directly by Dicey, so it is arguably consistent with his view of the Parliament Act as laid out above. Dicey's references to the procedural requirements of section 2 of the 1911 Act may also seem to point in this direction given that part of Wade's argument is that the section 2

102 A V Dicey and E C S Wade, Introduction to the Study of the Law of the Constitution (Macmillan \& Co 1950) x-xi. 103 Ibid lxv.

104 See, inter alia, Wade (n 99) footnotes 2, 19, 31.

105 Ibid 175.

106 The remainder of Wade's analysis restates this on the basis that an Act has been passed, rather than the case arising when it is still at Bill stage, see e.g. :'that Act like any other could be repealed by an ordinary Act of Crown, Lords and Commons without a referendum’ (ibid 190, emphasis added).

107 E C S Wade and G Godfrey Phillips, Constitutional Law (3rd edn, Longmans Green \& Co 1948) 39.

108 [2005] UKHL 56. 
requirements demonstrate that legislation passed under the 1911 Act is delegated legislation. ${ }^{109}$

There are, however, four pieces of evidence that indicate that the better reading of Dicey is that he did not agree with the delegated legislation argument, particularly when attention is paid not merely to the foreword but also to the body of the text. First, it should be noted that H W R Wade's argument rests on the claim that, while the procedure under the Parliament Act was sufficient for the legislation passed thereunder to be called an Act of Parliament, it was only in a sense which does not affect any question of sovereignty'. ${ }^{110}$ Dicey, as we have seen, addressed this question rather differently. Having considered the legislative ambit of the Parliament Act, Dicey moved then to the question of whether it had transformed 'the sovereignty of Parliament into the sovereignty of the King and the House of Commons'. ${ }^{111}$ Dicey's question therefore goes to the question of sovereignty and, as we have noted, simply reasserts the sovereignty of the Crown in Parliament. Second, Dicey argued that there is a potential bar to the operation of the Parliament Act - the royal veto - but was also clear that he believed this could be deployed against Bills passed by both Houses. ${ }^{112} \mathrm{He}$ did not argue that a judicial remedy exists. Third, Dicey could have placed more reliance on the time-based limitation of the Parliament Act, namely that the provisions of section 2 did not apply to Acts to extend Parliament beyond five years, to argue that there was a substantive limitation on what was possible under the 1911 Act. The fact that he chose not to do so is instructive, particularly as the question of whether Parliament can prolong itself even in the face of a previously passed statute was a key element in his argument about the nature of parliamentary supremacy. ${ }^{113}$ In the body of the text, Dicey argued that the 'standing proof' of parliamentary supremacy was that the Crown in Parliament, in violation of a prior Act, extended its duration from three to seven years. If the provisions of section 2 relating to duration were a limitation on powers conferred under the Parliament Act, as Dicey argued would have been the case if the septennial Act had been passed under the US Constitution, then it would have been a decisive argument against the sovereignty of the King and Commons. The fact that Dicey did not run this point is evidence that he did not think it held, and the natural basis on which he would hold this view was that, notwithstanding the wording of the 1911 Act, if push came to shove the five-year rule would be set aside in the same manner as the triennial Act. Fourth, and relatedly, Dicey argued that laws passed by the US Congress, like rules of the Great Eastern Railway Company, 'are at bottom simply "bye-laws", 114 which could be set aside for being ultra vires. This, of course, is a variant of the delegated legislation argument, but, again, it is not deployed against the Parliament Act in the foreword. While none of these pieces of evidence is conclusive, the logical inference of them when considered as a whole is that the reason Dicey did not address the delegated legislation argument is that he didn't consider it to apply to the Parliament Act.

109 Wade (n 99) 193-194.

110 Ibid 194.

111 Emphasis added.

112 Dicey (n 96) xxiii n 1.

113 Ibid 42-46.

114 Ibid 146. 


\section{Conclusion}

This article set out to provide some additional insights into the interaction between British constitutional law and imperial law in the interwar period. The expansion of the academic discipline in this period against a backdrop of increased interaction with colonial elites inevitably made its way into core textbooks on British constitutional law. This was understandably not uniform amongst authors, but it was notable that all of the textbooks considered for this article referred to imperial law to some extent. It was foreseeable that the statutory provisions relating to nationality would entangle British constitutional law in the consideration of imperial law. More surprising perhaps is the manner in which the English law relating to habeas corpus was directly influenced, to a greater and lesser degree, by developments in Nigeria, while the snide manner in which these precedents were treated by certain members of the academy is lamentable.

The interwar period also saw developments in core concepts, including parliamentary supremacy. This paper has endeavoured to show, however, that the basic idea of the manner and form objection was to be found within Dicey's own work, although it was not acknowledged at the time and has been subsequently misinterpreted. Ultimately, the question of whether Dicey did or did not adhere to the manner and form objection does not alter the debate as it stands today; the arguments stand or fall on their logic and coherence, rather than on whether they cohere more closely or loosely with Dicey's theory. It does, however, undermine claims that there is an 'orthodox' view to defend. Whether or not Dicey's views influenced the Australian jurisprudence on the question, it is inarguable that it was the Trethowan case and the academic commentary that popularised the objection. What this article has endeavoured to show, however, is that the influence of imperial law on British constitutional law at this time was, however, more widespread than in relation to a single conceptual issue; it spanned multiple topics of constitutional law. The egress of the British constitution was the constitution of the British Empire; which in turn became an ingress into British constitutional theory. 
